\title{
Feasibility Analysis and Measures for Recycling Textbooks in Universities
}

\begin{abstract}
Zhong Guo
Shandong Technology and Business University, Yantai, China

*Corresponding author. Email: 201511972@edtbu.edu.cn

ABSTRACT

Given our basic national conditions, it's essential for us to build a resource-conservative and environmentally friendly society, which is a traditional virtue of the Chinese nation, and also a vital guarantee for the sustainable and sound economic development in China. In this paper, the feasibility of recycling textbooks is analyzed through the annual changing rate of textbook contents from different categories, subjects, majors and course attributes in universities considering the role of university libraries in building a resource-conservative and environmental friendly society, the current status of textbooks recycling in universities, obstruction of textbook recycling in universities and problems in textbook recycling trials. Discuss the ratio of students recycling textbooks based on the ratio of each development direction planned by students, analyze the ratio of students willing to use recycled textbooks and the feasibility of recycling textbooks based on the economic status of students' families, the expenses of textbooks through questionnaires, and then elaborate the detailed rules and methods to build the library of recycled textbooks, and organize textbook recycling in universities.
\end{abstract}

Keywords: Conservation-oriented society, Library, Textbook recycling, Single subject examination method for textbook borrowing stacks in library, Timeliness of textbook.

\section{INTRODUCTION}

China is a big country with a large population, but extremely low resource occupancy per capita; With the constantly fast development of economy after reform and opening-up, people have gradually realized the importance of sustainable and sound development of economy by building a resource-conservative and environmentally friendly society.

\section{NECESSITY FOR RECYCLING TEXTBOOKS IN UNIVERSITIES}

General Secretary Jintao HU pointed out during the report of the 17th National Congress of the Communist Party of China: "Strengthen the conservation of energy and resources as well as the protection of ecological environment, and boost the sustainable development capacity. We should adhere to the basic state policy of conserving resources and protecting the environment, because it is vital to the immediate interests of the people as well as the survival and development of the Chinese nation. We must prioritize the construction of a resource-conservative and environmentally friendly society in industrial and modernized development strategies, and implement it in each institution and family. We should refine laws and regulations beneficial to energy and resource conservation and the protection of ecological environment, and speed up the formation of a sustainable development system. Implement the job responsibility system of energy conservation and emission reduction"[1]. General Secretary Jinping XI pointed out during the report of the 19th National Congress of the Communist Party of China: "We should speed up the transformation of ecological civilization system, and build a beautiful China", and "advocate simple, moderate, green, and low-carbon ways of life, and say no to extravagance and excessive consumption. Meanwhile, active measures should be taken to create energy-saving agencies, green families, green schools, green communities and green travels, etc."[2].

Currently, our country ranks the sixth across the globe in forest area and forest stock volume, but our quantity per capita only ranks the $1 / 6$ and $1 / 8$ of the world's quantity per capita [3]. It's an inevitable choice for us to recycle textbooks in universities, given our basic national conditions. Textbook recycling has become quite popular in developed countries, for 
instance, in American primary and secondary schools, their textbooks will be shared by at least 8 students, and the average service life of a book is 5 years. In contrast, our textbooks have become disposable "luxuries". Although free textbook recycling system has been built in rural primary and secondary schools since the spring of 2008, urban primary and secondary schools, especially universities still fail to realize textbook recycling. The current textbooks in domestic universities are mostly disposable. Since there are many courses in universities, and will cost students a lot of money in purchasing the textbooks, which are often sold out at a low price as waste papers, or directly threw away after finishing the classes. China is a big country with huge demand for resources, but low utilization rate, so resource recycling is essential. China has a huge college student group, and by recycling textbooks, we can not only save huge resources for the country, but also alleviate the economic burdens of college students, and cultivate students' self-quality, diligence and values.

By investigating different majors in universities, a college student will spend averagely RMB 1,000 in textbooks per year, and such books can reach to about 6,000 pages in total. By calculating as per about 30 million college students in our country, RMB 30 billion will be spent on buying textbooks per year, and 150 billion papers will be used. It's known to people that, the energy and resources consumed by paper-making industry and the pollutants emitted are astonishing, "1 ton of paper can make 229,000 A4 papers, but to produce these papers, about 3.75 tons of timbers should be consumed, equivalent to chopping down 14 trees that have grown for 8 years, and are $7 \mathrm{~m}$ in height and 8 inches in diameter [4]." Besides, about 100 tons of water will be consumed to produce 1 ton of paper, and the water polluted can reach to about 300 tons...... Based on the calculation, the annual consumption of paper used to make textbooks for university students is 655,022 tons, equivalent to chopping down about 9,170,308 trees and consuming 65,502,200 tons of water. If textbooks can be recycled for 5 times averagely, about RMB 19.2 billion, about 524,018 tons of paper, $7,336,246$ trees and 52,401,800 tons of water can be saved averagely per year......., which are all astonishing figures. It's essential to boost "green education", explore resources among numerous textbooks, and reduce wastes.

The most basic meaning of resource-conservative and environmentally friendly society is to: Use the fewest resources, to get the maximum economic and social benefits. We must adhere to building a resourceconservative and environmentally friendly society, given our national conditions. As a major component of the society, universities are obligated to take the lead in making full use of resources to build a resourceconservative and environmentally friendly society. Building a resource-conservative and environmentally friendly university is of great significance to implement the scientific outlook on development and build a harmonious campus. As the information service center of universities, libraries must integrate into the construction of the resource-conservative and environmentally friendly universities, to cultivate students' awareness to save energy, build an energysaving culture, advocate energy-saving civilization, and create a benign atmosphere for building a resourceconservative and environmentally friendly campus. Therefore, it's of great significance to recycle textbooks in universities.

\section{CURRENT STATUS OF TEXTBOOK RECYCLING AT HOME AND ABROAD}

Textbook recycling is no longer a new thing across the globe. Currently, the free textbook borrowing system has been implemented during compulsory education of primary and secondary schools in America, Canada, French, Japan and other developed countries, and since the textbooks provided for free are public properties, and are not owned by individuals, it has ensured the feasibility of applying administrative systems in textbook recycling during the compulsory education of primary and secondary schools, and in order to promote textbook recycling, students are requested to cherish them from childhood, and there are even different legal regulations on cherishing textbooks. As people from all walks of the society are calling for textbook recycling, the state has issued a series of policies: In the Temporary Administrative Methods for Providing Free Textbooks to Students from Families with Financial Difficulties during the Compulsory Education in Rural Areas jointly prepared by the Ministry of Finance and the Ministry of Education in 2004, it put forward that "the state encourages textbook recycling". The Ministry of Education and the Ministry of Finance jointly published Opinions on Providing Compulsory Education Textbooks and Recycling Partial Textbooks Comprehensively in Rural Areas in December 2007, which pointed out that: The textbook recycling system has been set up for partial courses, including Science, Music, Art, and Information Technology in primary schools as well as Music, Art, Information Technology and Sports and Health in secondary schools from the spring semester of 2008. So far, it has been implemented in most provinces, cities and autonomous regions of the country.

However, no country has set up the textbook recycling system in their universities yet. Textbook recycling for undergraduates in America, Canada, French, Japan and other developed countries depends fully on market-oriented operations. Students can borrow textbooks from the library, and buy those they cannot borrow from the library by themselves. Each university has a special book store for used textbooks independently operated by students. Textbook recycling 
has become a popular trend. While books used when studying for master and doctor degree are basically borrowed from the library. Textbooks in our universities are basically purchased and then distributed uniformly. As college students and people from all walks of life have called for the action, some universities allow students to solve textbooks by themselves, but due to the lack of unified organization management and systems, there are many problems.

\section{FACTORS AFFECTING TEXTBOOK RECYCLING IN UNIVERSITIES}

\subsection{It Depends on the Ownership of College Textbooks}

College textbooks are purchased by students independently, and are private properties owned by students. In that case, the state cannot formulate detailed policies and methods for recycling free textbooks provided for compulsory education in primary and secondary schools. If the ownership of college textbooks cannot be solved, textbook recycling in universities can only be promoted by publicizing education, and improving students' awareness slowly. What's the proportion of students that can use the recycled textbooks? How many times can a textbook be recycled? How long will it last? That's doubtable

\subsection{Benefits for Departments Involved in Textbook Issuing are the Biggest Barrier Blocking Textbook Recycling}

Firstly, there are blocks from college students, and most universities are still adopting unified ordering and compulsory issuing mode. Textbooks are sold to students at the original cost, but the school enjoys $20 \%$ $30 \%$ off, when purchasing from publishers. For a university with 20,000 students, the annual profit can reach to RMB 2 million-3 million. Secondly, there are blocks from the press and publisher, and if college textbooks can be recycled for 4 years, the annual loss incurred to the publishing industry will reach to above 10 billion shares. What's the profit to publish textbooks? For outsiders, it's difficult to say. By entering "Top Ten Industries with Windfall Profits in China" on Baidu, you will find the textbook publishing industry. We bought a textbook of advanced mathematics from a bookstore near a school, and asked about the discount? We got the answer of $30 \%$ off, and after seeing we were hesitating, the clerk supplemented that the book was the legal copy! And the illegal copy was $70 \%$ off. Thirdly, several types of books are included by competent education departments in the compulsory list. Fourthly, there are also blocks from the competent textbook department (textbook handler) in universities, for publishing departments will provide school and textbook handlers with benefits either in public or in private, which has become a public secrete. According to the report of Jiangsu Provincial Work-related Crime Prevention Website on June 8, 2006: "Jiangsu Provincial Procuratorial Organ dug out a series of college textbook kickback cases after more than two years of investigation: Among the 115 universities in Jiangsu, 109 schools have been found to be involved in certain cases, and more than 130 commercial bribery cases have been registered'[5]. As for the root cause, "from the perspective of economics, textbooks are special as a commodity, and the particularity can be reflected from two aspects. First of all, it's a commodity separating the consuming subject and consumption decision makers......"[6]. "The consumers have been deprived of their right to make decisions, and are weak to maintain their consumer rights and interests, but they are quite dependent on government agents in the consumption. This is an extremely rare phenomenon in the consumption of other commodities"[6]. This is similar to the corruption phenomenon in government purchasing and intensive purchasing. As the agent of textbook purchasers, such as the school (textbook department and handler), they will meet their personal interests (or the interests of a few people or institutions) at the cost of damaging the interests of the purchaser (student) and the country (or institutions), and the public resources. As the purchasers of textbooks, students have no right to decide. Fifthly, there are blocks from the majority of teachers. The first thing lies in being afraid that the recycling of textbooks will bring inconvenience to lectures; fourthly, the second thing lies in the use of self-compiled textbooks. Now, almost all universities pursue the use rate of self-compiled textbooks. Although the level of textbooks is very low and only their own students choose them, their own students can use these textbooks for several successive sessions, which will not cause money loss because of the large scale of the schools. Moreover, there are so many advantages in compiled textbooks.

\subsection{It is Worried that the Recycling of Textbooks will Affect the Quality of Teaching}

If students can decide to buy textbooks on their own, we are wondering whether there will be a variety of textbooks, and even some students do not buy textbooks, thus affecting the quality of teaching

\subsection{Ideas and Book use Habits Hinder the Recycling of Textbooks}

Many students are not interested in the recycling of textbooks due to the poor saving consciousness and environmental awareness. They think that textbooks will not cost much, which will not have any impact on their own lives. They do not consider China's resources and environmental problems and do not understand it from the perspective of saving resources. Some students think 
that the recycling of textbooks is not convenient, because these students do not have the habit of taking notes in class, they are always willing to write and draw in books, and they do not form a good habit of taking good care of books

\section{FEASIBILITY ANALYSIS FOR RECYCLING TEXTBOOKS IN UNIVERSITIES}

Table 1. Data analysis of content changes in science textbooks

\begin{tabular}{|c|c|c|c|c|}
\hline & $\begin{array}{c}3 \text {-year } \\
\text { change rate }\end{array}$ & 5-year change & $\begin{array}{c}\text { 7-year } \\
\text { rate }\end{array}$ & $1 \%$-year change \\
\hline $\begin{array}{c}\text { Professional basic } \\
\text { courses }\end{array}$ & $0 \%$ & $0.5 \%$ & $5 \%$ & $2 \%$ \\
\hline $\begin{array}{c}\text { Public common } \\
\text { courses }\end{array}$ & $1 \%$ & $2 \%$ & $2 \%$ & $3 \%$ \\
\hline $\begin{array}{l}\text { Directional basic } \\
\text { professional } \\
\text { courses }\end{array}$ & $0.5 \%$ & $1 \%$ & $6 \%$ & $8 \%$ \\
\hline $\begin{array}{c}\text { Directional } \\
\text { professional courses }\end{array}$ & $1 \%$ & $3 \%$ & $40 \%$ & $50 \%$ \\
\hline $\begin{array}{c}\text { Current affairs and } \\
\text { politics class }\end{array}$ & $20 \%$ & $30 \%$ & & $10 \%$ \\
\hline
\end{tabular}

Table 2. Data analysis of content changes in engineering textbooks

\begin{tabular}{|c|c|c|c|c|}
\hline & 3-year change & $\begin{array}{c}5 \text {-year } \\
\text { change rate }\end{array}$ & $\begin{array}{c}7 \text {-year } \\
\text { change rate }\end{array}$ & rate \\
\hline $\begin{array}{c}\text { Professional basic } \\
\text { courses }\end{array}$ & $1 \%$ & $3 \%$ & $5 \%$ & $8 \%$ \\
\hline $\begin{array}{c}\text { Public common } \\
\text { courses }\end{array}$ & $0.5 \%$ & $2.5 \%$ & $3 \%$ & $5 \%$ \\
\hline $\begin{array}{c}\text { Directional basic } \\
\text { professional } \\
\text { courses }\end{array}$ & $1 \%$ & $3 \%$ & $5 \%$ & $6 \%$ \\
\hline $\begin{array}{c}\text { Directional } \\
\text { professional courses }\end{array}$ & $2 \%$ & $4 \%$ & $6 \%$ & $10 \%$ \\
\hline $\begin{array}{c}\text { Current affairs and } \\
\text { politics class }\end{array}$ & $20 \%$ & $30 \%$ & $40 \%$ & $50 \%$ \\
\hline
\end{tabular}

Table 3. Data analysis of content changes in economic management textbooks

\begin{tabular}{|c|c|c|c|c|}
\hline & $\begin{array}{c}\text { 3-year } \\
\text { change rate }\end{array}$ & rate & $\begin{array}{c}\text { 7-year } \\
\text { change rate }\end{array}$ & 10-year change \\
\hline $\begin{array}{c}\text { Professional basic } \\
\text { courses }\end{array}$ & $0.5 \%$ & $1 \%$ & $2 \%$ & $3 \%$ \\
\hline
\end{tabular}




\begin{tabular}{|l|c|c|c|c|}
\hline \multicolumn{2}{|c|}{ Table 3, cont } \\
$\begin{array}{c}\text { Public common } \\
\text { courses }\end{array}$ & $0.5 \%$ & $2.5 \%$ & $3 \%$ & $5 \%$ \\
\hline $\begin{array}{l}\text { Directional basic } \\
\text { professional } \\
\text { courses }\end{array}$ & $1 \%$ & $3 \%$ & $5 \%$ & $7 \%$ \\
\hline $\begin{array}{l}\text { Directional } \\
\text { professional courses }\end{array}$ & $2 \%$ & $4 \%$ & $6 \%$ & $8 \%$ \\
\hline $\begin{array}{c}\text { Current affairs and } \\
\text { politics class }\end{array}$ & $20 \%$ & $30 \%$ & $40 \%$ & $50 \%$ \\
\hline
\end{tabular}

Table 4. Data analysis of content changes in literature and history textbooks

\begin{tabular}{|l|c|c|c|c|}
\hline & $\begin{array}{c}3 \text {-year } \\
\text { change rate }\end{array}$ & $\begin{array}{c}5 \text {-year change } \\
\text { rate }\end{array}$ & $\begin{array}{c}7 \text {-year } \\
\text { change rate }\end{array}$ & $\begin{array}{c}10 \text {-year } \\
\text { change rate }\end{array}$ \\
\hline $\begin{array}{c}\text { Professional basic } \\
\text { courses }\end{array}$ & $0.5 \%$ & $1 \%$ & $1.5 \%$ & $2 \%$ \\
\hline $\begin{array}{c}\text { Public common } \\
\text { courses }\end{array}$ & $0.5 \%$ & $2.5 \%$ & $3 \%$ & $5 \%$ \\
\hline $\begin{array}{l}\text { Directional } \\
\text { professional } \\
\text { courses }\end{array}$ & $0.5 \%$ & $1 \%$ & $2 \%$ & $3 \%$ \\
\hline $\begin{array}{c}\text { Directional } \\
\text { professional courses }\end{array}$ & $1 \%$ & $2 \%$ & $3 \%$ & $4 \%$ \\
\hline $\begin{array}{c}\text { Current affairs and } \\
\text { politics class }\end{array}$ & $20 \%$ & $30 \%$ & $40 \%$ & $50 \%$ \\
\hline
\end{tabular}

From the above various categories and the change rates of contents of various courses, we can see that the contents of professional basic courses, public common courses, directional professional basic courses and directional professional courses in science, engineering, economic management, literature and history have not changed much in the past ten years. In addition to current affairs and politics courses, the textbooks of other courses have been in use for more than three years before new versions are published. In addition, the characteristics of single subject examination in universities, and the timeliness of textbooks in universities also make students willing to donate or transfer the textbooks, so the recycling of textbooks can be carried out for a long time. As for the current affairs and politics textbooks, the new version is usually issued in two years. Due to the rapid change and no reservation value, almost all students are willing to donate or transfer them, and the students who use them are also willing to use the old textbooks. Although the textbooks can only be recycled once or twice, the coverage of repeated use is large.

\subsection{From the Analysis of Students' Dependence on Textbooks}

Shandong Technology and Business University is an ordinary undergraduate university. We have investigated whether students of different grades want to continue to study for taking the postgraduate entrance examination. The investigation results show that about $85 \%$ of the students have the intention to take the postgraduate entrance examination when they first enter the university, and about 50\% of the sophomore students have the intention to take the postgraduate entrance examination, about $40 \%$ of the junior students have the intention to take part in the postgraduate entrance examination, about $30 \%$ of the senior students have the intention to take part in the postgraduate entrance examination, and about $20 \%$ to $40 \%$ of the students finally take part in the postgraduate entrance examination. This includes many students who do not want to take the postgraduate entrance examination but do not find a suitable job to take part in the postgraduate entrance examination for "taking chance"! We 
investigate the students who don't have plan to take the postgraduate entrance examination. Most of them are willing to donate or transfer the used textbooks at a lower price. The textbooks of these students are well preserved! It can be seen that the source of textbooks for the recycling of textbooks is fully guaranteed.

\subsection{From the Analysis of the Conditions of Universities}

All universities have modern libraries, rich electronic resources and paper books, professional librarians and advanced library management system, which provide hardware guarantee for the recycling of textbooks. For the management system of Chinese universities for college students, there are Party and Youth League organizations at all levels and the professional counselors of various departments, as well as the student unions and student associations at all levels of the universities and colleges. The universities have a strong ability to educate the students' awareness of environmental protection and organize to collect recycling textbooks resources, which provides strong support for the recycling of textbooks.

\subsection{From the Analysis of Textbook Acquisition Expenses Investigation and Students' Recognition to the Recycling of Textbooks}

More than $70 \%$ of the students in Shandong Technology and Business University come from rural areas, and their families are not well-off. The proportion of poor students is about $20 \%$. Statistics show that the textbook acquisition expenses of undergraduates is about RMB 1,000 every year. The investigation shows that the monthly living expenses of students in Shandong Technology and Business University are about RMB 1,700 for freshmen, RMB 1,800 for sophomores, RMB 1,900 for juniors and RMB 2,200 for seniors. The textbook expenses accounts for a large proportion, especially for poor students who will feel burdened. The sample investigation shows that almost all poor college students and college students who have no intention to take the postgraduate entrance examination are willing to donate and sell their used textbooks at a low price. Only a few of the students who take the postgraduate entrance examination are unwilling to donate and sell their books at a low price. Almost all and most of the poor students say that as long as the old textbooks are well preserved, they can accept the use of recycled textbooks.

In addition, the author analyzes the intact degree of textbooks [7], the construction of trading platform for used books in universities [8], and the feasibility of recycling textbooks in universities

\section{MEASURES TO RECYCLE TEXTBOOKS}

How to realize the recycling of college textbooks and avoid the problems in the recycling of textbooks in some universities in our country, we suggest that the state should regulate the unified management of university libraries, establish textbook borrowing stacks in the national university libraries, and cancel the college textbook departments. It is suggested that teachers should guide correctly in the teaching process.

\subsection{The Establishment of Textbook Borrowing Stacks in Library is the Fundamental Guarantee for the Full and Repeated use of Textbooks}

The main reason why college textbooks can not be recycled like some textbooks of free compulsory education is that textbooks are owned by students. Therefore, the textbook borrowing stacks in library are established to make the university libraries uniformly operate and manage the recycled textbooks and "deprive" students of the ownership of textbooks. For recycled textbooks, students can borrow them like other books in the library, or buy them at a low price.

\subsection{The Source of Textbooks of the Textbook Borrowing Stacks in Library}

First of all, it is based on the textbook use cycle of half a year, one cycle a year. We carry out the activity of Starting from Me to Recycle Textbooks for "Building a Resource-conservative and Environmentally Friendly University" in the whole university in April and October of every year. Publicity activities should be carried out in secondary colleges and classes. The general League branch and counselors should take corresponding responsibilities. Given our basic national conditions, it's essential for us to build a resource-conservative and environmentally friendly society, which is a traditional virtue of the Chinese nation, and also a vital guarantee for the sustainable and sound economic development in China. All students should truly have such thought. The school publishes recyclable textbooks and their versions on the campus website, library website and educational administration website. Textbook recycling can be carried out in two forms: donation and low price acquisition. Secondly, because the second-hand textbooks purchased by students themselves, donated by students and purchased from students at a low price are far from meeting the needs of all students in the school, the insufficient textbooks are ordered by the textbook borrowing stacks in school library. 


\subsection{The Establishment and Management of Textbook Borrowing Stacks in Library}

The recycling of textbooks is a "borrowing and purchasing method", so the textbook borrowing stacks in library must be under the unified management of the library. Due to the particularity of using time and scope, the operation should be carried out as follows: According to the number of collections and textbooks recovered from the activities of donating and recycling textbooks in the activity of Starting from Me to Recycle Textbooks for "Building a Resource-conservative and Environmentally Friendly University" in the whole university in April and October of every year, the subscription and payment time of textbooks for the next semester (for the students who are not willing to use recycled textbooks and those who do not participate in recycled textbooks) is counted by class. In June and December of each year, and in winter and summer vacation, the textbook borrowing stacks in library decides to order textbooks for the next semester according to the demand of textbooks in the next semester, the number of second-hand textbooks and the number of textbooks purchased by students. In order to coordinate with the recycling of textbooks, "textbook" class should be added to the category of books in library. The longest return period of textbooks should be 8 months, and the number of books allowed to be borrowed should meet the needs of teaching. The same bar code can be used for the same version of textbook, and the collection of textbook information should be simplified: Textbook name, version, price, etc. Textbooks do not need to be put on shelves. They can be piled up in rows and layers. A textbook sample bookshelf should be set up. The sample book should be marked with location of the book for students to borrow. Ordinary universities only offer one or two hundred courses, so the workload is not very large. Every school should complete the recycling of textbooks within three to four years, which should start with public basic courses. More than $80 \%$ of university textbooks should be recycled.

\subsection{The Reform of the use of Textbooks of Teachers Promotes the Recycling of Textbooks}

In many universities in Japan, the United States and other countries, as well as individual universities in China, some professional schools do not organize students to buy textbooks uniformly. Teachers only give a bibliography for students who will borrow the textbooks according to the bibliography. The contents of teachers' lectures are included in any bibliography. It is found that students' learning effect is better in this way, which is helpful to develop good reading habits and the ability to use book information, and also increases students' knowledge and good reading habits as well. Teachers can also require unifying textbooks for teaching, but not unifying the version. Based on the analysis of the change rate of textbook content above, except for current affairs and politics courses, other courses have little change. The experiment shows that if the teacher makes clear the reasons and trends of the content changes in different versions, it will receive unexpected results.

\section{CONCLUSIONS}

Based on the investigation and analysis of the content change data and characteristics of college textbooks, the classification analysis of college students' future career planning, the analysis of the pressure of textbook expenses on students, the characteristics of single subject examination in universities, and the timeliness of college textbooks, we can find out that $80 \%$ of the students in universities are willing to use or partially use recycled textbooks. China's education management system has incomparable advantages in cultivating students' awareness of conservation, building conservation culture, advocating conservation civilization, and building resource-conservative and environmentally friendly campus. Moreover, the construction of the textbook borrowing stacks in library completely solves the ownership problem of college textbooks, paves the way for the recycling of college textbooks, and makes it possible to formulate the recycling system of college textbooks. The recycling of university textbooks makes the profit cake of college textbooks smaller, which will effectively prevent and reduce all kinds of corruption in the process of textbook distribution. The construction of the textbook borrowing stacks in library makes the use of college students textbooks at a low cost, which will make pirated textbooks, printed textbooks and photocopied textbooks have no value, effectively protect the interests of publishers and authors, greatly enhance the awareness of intellectual property protection among college students, and form a social atmosphere of respecting knowledge. It is required for the construction of socialist spiritual civilization. The proper arrangement for the recycling of college textbooks will not reduce the quality of teaching, but also improve the quality of teaching - if we can complete the work of recycling textbooks and ordering textbooks for the next semester one week before the end of the semester, and require students to borrow textbooks for the next semester before the vocation, some students will definitely preview and understand the teaching content of the next semester in this way, which plays an important role in developing students' good learning habits and cultivating their attitude of studying science and culture assiduously. We should strictly control the revision of textbooks, and resolutely crack down on the phenomenon of false revision. If there are few changes in textbooks, we can take the method that teachers send the changed contents to students in the form of handouts 
or publish them on the Internet for students to download. Moreover, we should also encourage the improvement of textbooks. Not only that, the recycling of college textbooks will also provide convenient conditions for the implementation of flexible education system and credit system in universities. The recycling use of college textbooks conforms to the voice of the majority of students and the development and trend of history. The establishment of textbook recycling mechanism in universities is not only the need of building a conservation-oriented society, but also the need of the construction and development of university libraries, and also the need of cultivating talents in universities. The formulation of textbook recycling system is the most perfect solution [9]. We firmly believe that textbook recycling, beneficial to the country and the people, will be gradually realized in universities under the leadership of the Ministry of Education and the support of education authorities at all levels!

\section{REFERENCES}

[1] Jintao HU, Hold High the Great Banner of Socialism with Chinese Characteristics and Strive for New Victories in Building a Moderately Prosperous Society in All Respects - Report at the 17th National People's Congress of the Communist Party of China on October 15, 2007.

[2] Jinping XI, Secure a Decisive Victory in Building a Moderately Prosperous Society in All Respects and Strive for the Great Success of Socialism with Chinese Characteristics for a New Era - Report at the 19th National Congress of the Communist Party of China on October 18, 2017

[3] Peng XUE, An Analysis of Achieve Energy-saving and Pollution Reducing in Macro Scope, Research on Financial and Economic Issues, Issue 9, 2008

[4] Sina News Center,http://news.sina.com.cn/o/201003-24/063817264824s.shtml.

[5] "More than 130 bribery cases involving 109 universities in Jiangsu Province have been filed", Jiangsu Province Duty Crime Prevention Network http://www.js.yfw.com.cn/shownews.asp?id=5508 3

[6] Rong WANG, Yun LUO, Lijuan ZHANG, Thought on the Supply Mechanism of Textbooks for Primary and Secondary Schools in China, China Education and Research Computer Network, http://www.eol.cn/20030228/3078600.shtml

[7] Xiuwen YU, Mengke DING, Yujing LIU, Mingda ZHANG, Xinna SUN, Zijie ZHENG, Yue LIU, Feasibility Study on Textbook Recycling of Beihua University -- Taking South Campus as an Example,
Mathematics Learning and Research, December 5, 2019.

[8] Juan GUO, Development Possibility of Secondhand Book Trading Platform in Colleges and Universities, Chinese \& Foreign Entrepreneurs, February 15, 2019.

[9] Qian CHEN, Chengzhi FANG, Research on Textbook Recycling System, Journal of Changchun Education Institute, May 2018. 